\author{
(online) = ISSN $2285-3642$ \\ ISSN-L = $2285-3642$ \\ Journal of Economic Development, Environment and People \\ Volume 7, Issue 1, 2018 \\ URL: http://jedep.spiruharet.ro \\ e-mail: office jedep@spiruharet.ro
}

\title{
Qualitative research methodology in social sciences and related subjects
}

\author{
Haradhan Kumar MOHAJAN ${ }^{1}$, \\ ${ }^{1}$ Premier University, Chittagong, Bangladesh, Tel: +8801716397232, Email: haradhan1971@gmail.com
}

\begin{abstract}
This literature review paper discusses the proper use of qualitative research methodology to discuss several research aspects for the improvement of the readers' skill. During the last few decades, the use of qualitative research has been increased in many institutions. It can be used to explore several areas of human behavior for the development of organizations. The purpose of this study is to provide inspirations to the new researchers for the development of their qualitative articles. The paper analyzes the design of qualitative research giving some methodological suggestions to make it explicable to the reader. In this paper, an attempt has been taken to study the background of the qualitative research methodology in social sciences and some other related subjects, along with the importance, and main features of the study.
\end{abstract}

Keywords: Research methodology, qualitative research, phenomenology, ethnography, narrative approach, grounded theory, content analysis, action research, historical research, case study

JEL Codes: $Y 90$

\section{Introduction}

Every research must involve an explicit, disciplined, systematic (planned, ordered, and public) approach to find out most appropriate results. Qualitative research is inductive in nature, and the researcher generally explores meanings and insights in a given situation [Strauss \& Corbin, 2008; Levitt et al., 2017]. It refers to a range of data collection and analysis techniques that use purposive sampling and semistructured, open-ended interviews [Dudwick et al., 2006; Gopaldas, 2016].

It is described as an effective model that occurs in a natural setting and enables the researcher to develop a level of detail from high involvement in the actual experiences [Creswell, 2009]. The research consists of a set of interpretive material practices that makes the world visible. It is multi-method in focus, involving an interpretive, naturalistic approach to its subject matter [Denzin \& Lincoln, 2005]. In addition, is a type of social science research that collects and works with non-numerical data that seeks to interpret meaning from these data that help us to understand social life through the study of targeted populations or places [Punch, 2013]. It is the observations and interpretations of people's perception of different events, and it takes the snapshot of the people's perception in a natural setting [Gentles et al., 2015]. It investigates local knowledge and understanding of a given program, people's experiences, meanings and relationships, and social processes and contextual factors that marginalize a group of people. We can see almost none description, because it formulates and builds new theories [Leedy \& Ormrod, 2001]. It focuses 


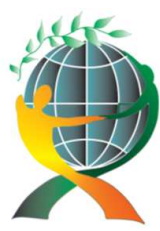

\author{
(online) $=$ ISSN $2285-3642$ \\ ISSN-L = $2285-3642$ \\ Journal of Economic Development, Environment and People \\ Volume 7, Issue 1, 2018 \\ URL: http://jedep.spiruharet.ro \\ e-mail: office jedep@spiruharet.ro
}

on words rather than numbers, this type of research observes the world in its natural setting, interpreting situations for understanding the meanings that people make from day to day life [Walia, 2015].

Qualitative research comprises of the following methods: logic, ethnography, discourse analysis, case study, open-ended interview, participant observation, counseling, therapy, grounded theory, biography, comparative method, introspection, casuistry, focus group, literary criticism, meditation practice, historical research, etc. [Cibangu, 2012].

Qualitative research is a form of social action that stresses on the way of people interpret, and make sense of their experiences to understand the social reality of individuals. It makes the use of interviews, diaries, journals, classroom observations and immersions; and open-ended questionnaires to obtain, analyze, and interpret the data content analysis of visual and textual materials, and oral history [Zohrabi, 2013]. It is exploratory, and seeks to explain 'how' and 'why' a particular social phenomenon, or program, operates as it does in a particular context. It tries to help us to understand the social world in which we live, and why things are the way they are [Polkinghorne, 2005].

It has gained more and more area in the social domain. It aims to provide a detail understanding into human behavior, emotion, attitudes, and experiences [Tong et al., 2012]. The main paradigms within the qualitative research are positivist, interpretive, and critical paradigms [Punch, 2013]. It is used to explore the behavior, perspectives, feelings, and experiences of people, and what lies at the core of their lives. The basis of it lies in the interpretive approach to social reality, and in the description of the lived experience of human beings [Atkinson et al., 2001]. It has a profound impact on the research area of education, health care, nursing, sociology, anthropology, psychology, management, information systems, etc. [Denzin \& Lincoln, 2005].

Qualitative researchers are interested in people's belief, experience, and meaning systems from the perspective of the people. Qualitative research does not include statistical analysis and empirical calculation [Brink, 1993]. The roots of qualitative research lie in social and cultural anthropology, philosophy, psychology, history, and sociology. The goal of the qualitative tradition is a 'deep understanding of the particular' [Domholdt, 1993]. The purpose of qualitative research is to describe and interpret issues or phenomena systematically from the point of view of the individual or population being studied, and to generate new concepts and theories. The choice of methodology is directed by the questions being raised [Viswambharan \& Priya, 2016].

Recently interest in social sciences of qualitative research is growing remarkably. The rapid rise of qualitative research to prominence in scientific communities; considerable debate has ensued regarding epistemological, philosophical, and methodological issues [Spencer et al., 2003]..

\title{
2. Literature review
}

Burns and Grove [2009] have provided their opinions that qualitative research is a systematic and subjective approach to highlight and explain daily life experiences, and to further give them proper meaning. Alberto Crescentini and Giuditta Mainardi have presented some guidelines, and suggestions for the preparation of a good qualitative research paper [Crescentini \& Mainardi, 2009].

Svend Brinkmann, Michael Hviid Jacobsen, and Søren Kristiansen have discussed six histories of qualitative research as: i) the conceptual, ii) the internal, iii) the marginalizing, iv) the repressed, v) the 


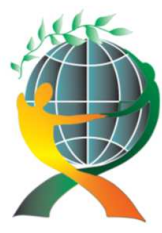

\author{
(online) $=$ ISSN $2285-3642$ \\ ISSN-L = $2285-3642$ \\ Journal of Economic Development, Environment and People \\ Volume 7, Issue 1, 2018 \\ URL: $\underline{\text { http://jedep.spiruharet.ro }}$ \\ e-mail: office jedep@spiruharet.ro
}

social, and vi) the technological histories of qualitative research [Brinkmann et al., 2014]. Md Shidur Rahman has discussed the advantages and disadvantages of using qualitative and quantitative approaches and methods in language [Rahman, 2017]. Looi Theam Choy has compared strengths and weaknesses of both qualitative and quantitative research methodologies in social sciences [Choy, 2014].

In the grounded theory qualitative method has used by Williams and Irurita [2005] to study the personal control and emotional comfort of hospitalized patients. They conducted interviews with 40 patients; and have 75 hours of field observations. Personal control referred to the ability of patients to influence their environment; emotional comfort was defined as a state of relaxation that affected the physical status of the patient.

In a case study of launching a product on a new market, Luminiţa Pistol and Rocsana Bucea-ManeaTonis have applied conjoint analysis approach to imitate and determine the optimal marketing mix for a Romanian company that struggles to face the market higher competition. They have tried to show how to use marketing simulation, more precisely conjoint analysis, in evaluating the market conditions when launching a new product on a new market [Pistol \& Bucea-Manea-Tonis, 2017]. Hezi Aviram Shayb, in a case study, has analyzed the success stories of some of the biggest and strongest companies in the world. He has also shown that there are some risks when one runs his/her business. He has stressed on setting up a strong plan in dealing with crisis, a business organization needs reliable, efficient and effective tools in business organizations [Shayb, 2017]. Rocsana Bucea-Manea-Joniș and Radu Bucea-Manea-Toniș have studied a case of Romanian SMEs that focus on technical elements for collecting data from Romanian SMEs managers and save it in a MySql database [Bucea-Manea-Toniș \& Bucea-Manea-Toniș, 2017].

Jenny Edwards provides information about conducting action research on the effects of cognitive coaching and adaptive schools. She shows the ways of formulating research questions, selecting the setting, determining the participants, choosing the procedures, applying to Institutional Review Boards, writing grants, analyzing the data, and sharing the findings [Edwards, 2016]. Vieri Maestrini, Davide Luzzini, Abraham B. (Rami) Shani, and Filomena Canterino have investigated the potentialities of action research within purchasing and supply management research, focusing in particular on buyer-supplier relationship issues [Maestrini et al., 2016]. Joseph A. Maxwell reviews earlier research, in both the natural and social sciences that clearly integrated qualitative and quantitative approaches and methods, and discusses some contemporary research traditions [Maxwell, 2016].

In the content analysis, the research report has five sections [Williams, 2007]: i) the description of the materials studied, ii) the characteristics and qualities studied, iii) a description of the methodology, iv) the statistical analysis showing the frequency table, and v) drawing conclusions about the patterns, themes, or biases found in the human communications and data collection. Natasha Constant and Liz Roberts have observed that narrative is rarely adopted as a form of evaluation in research area. They have conjectured that narrative as an evaluative approach for research projects with a core science communication element and offer several narrative methods to be trialed [Constant \& Roberts, 2017]. Greenhill et al. [2016] used narrative methods to assess incidents of play, socialization, fun, and amusement to consider how social interactions relate to the gaming elements of citizen science platforms.

Kalpita Bhar Paul has introduced an interpretive approach of phenomenological research methodology in environmental philosophy [Paul, 2017]. Kimberly M. Jones-Goods and Marquis Carter Grant have 


\author{
(online) = ISSN $2285-3642$ \\ ISSN-L = $2285-3642$ \\ Journal of Economic Development, Environment and People \\ Volume 7, Issue 1, 2018 \\ URL: http://jedep.spiruharet.ro \\ e-mail: office jedep@spiruharet.ro
}

explored the factors affecting elementary teacher's ability to understand the academic needs of their racially, culturally, and ethnically diverse special education students, and the ways in which their values and beliefs influenced their use of culturally responsive practices in the special education classroom [JonesGoods \& Grant, 2016].

J. A. Hatch identifies five research paradigms: positivist, post-positivist, constructivist, critical/feminist, and poststructuralist; and poses ontological, epistemological, and methodological questions for each [Hatch, 2002]. In a review paper Haradhan Kumar Mohajan has discussed reliability and validity of a good research that increase transparency, and decrease opportunities to insert researcher bias in qualitative research [Mohajan, 2017].

\title{
3. Objective of the study
}

This study analyzes the qualitative research methodology for the new researchers. We have tried to highlight aspects of qualitative research strategy in social sciences and related subjects. This study will bear the following specific objectives:

[? To provide a basic understanding of qualitative research.

[? To equip with sufficient information to appreciate how qualitative research is undertaken.

[? To highlight different types of qualitative research.

[? To describe in brief the characteristics, strengths and weaknesses, advantages, and importance of qualitative research.

\section{Methodology of the study}

Research methodology indicates the logic of development of the process used to generate theory that is procedural framework within which the research is conducted [Remenyi et al., 1998]. The methodology of this article is to discuss aspects of qualitative research in social sciences and some related subjects in some details. The data were collected to achieve the result for the purpose and scope of this study. In this study, secondary data are used to enrich the article. For the collection of secondary data, we have used both published and unpublished data sources.

The published data are collected from:

i) various publications of foreign governments or of international bodies and their subsidiary organizations,

ii) various research reports are prepared by research scholars, universities, economists, etc., in different fields,

iii) books of various authors, handbooks, theses, magazines, and newspapers,

iv) various sources from university libraries,

v) technical and trade journals,

vi) websites, and

vii) public records and statistics, historical documents, and other sources of published information. 


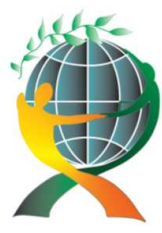

\author{
(online) $=$ ISSN $2285-3642$ \\ ISSN-L = $2285-3642$ \\ Journal of Economic Development, Environment and People \\ Volume 7, Issue 1, 2018 \\ URL: http://jedep.spiruharet.ro \\ e-mail: office jedep@spiruharet.ro
}

The sources are found in diaries, letters, unpublished biographies and autobiographies, and also from scholars and research workers, trade associations, labor bureaus, and other public/private individuals and organizations.

\title{
5. Historical background
}

We cannot ignore the experiences for the present and future development. Historical research is founded on identification, analysis, and interpretation of old texts, which is one of the functions of hermeneutics. A scientific method seeks to understand a text and to interpret it to other people. The folk wisdom expresses, "The nation which forgets its history is forced to repeat the same mistakes" [Špiláčková, 2012]. To understand qualitative research it is pertinent to know the brief history of research, its traditions and philosophical foundation. History writing in qualitative research is not only just discussing the past but also about prospects for the future. Medieval philosophers of scholasticism distinguished qualia (the qualities of things) from quanta (the quantities) hundreds of years ago. The 17th centurion empiricist philosopher John Locke argued that primary qualities were thought to be independent of observers, such as, extension, number, and solidity. Secondary qualities were thought to be produced as effects in observers, such as, colors, tastes, and smells. The post-medieval philosophers, such as, Descartes, Locke, Hume, etc., confined the secondary qualities to the subjective mind [Brinkmann et al., 2014]. European intellectual history has begins in the 18th century. Modern scientific thought emerged during the Scientific Revolution by Newton and Galileo. French philosopher August Comte founder of sociology merged rationalism and empiricism in a new dogma called positivism [Walia, 2015].

Anthropologists and sociologists first used qualitative research as a method of inquiry in the early decades of the 20th century. For example, in the 1920s and 1930s, social anthropologists Mainowski [1920] and Mead [1935], and sociologists Park and Burgess [1925] had remarkable contribution on qualitative research. The period from 1900 to 1945 is called the traditional age of qualitative research. During this period, qualitative data analysis aimed at a more or less objective description of social phenomena in society or in other cultures. The positivist paradigm reflects the principles of scientific enquiry of qualitative research. For example, the Chi-cago School in sociology and the research of Malinowski in ethnography are formed in the traditional age [Denzin \& Lincoln, 2005].

Much of the literature of qualitative research and its textbooks begins in the 1960s and 1970s [Flick, 2014]. The period from 1950 to 1970 is the second stage, called the golden age of qualitative research, and has experienced modern approach (the modernist phase). In this period, data analysis was driven by various ways of coding for materials often obtained from participant observation. The symbolic interaction perspective [Becker et al., 1961], the development of the grounded theory [Glaser \& Strauss, 1967], the attempt in ethnography [Garfinkel, 1967] have commenced the modern qualitative researches [Spradley, 1980].

During 1970 to 1986, blurred genres, a variety of new interpretive, qualitative perspectives, such as, hermeneutics, structuralism, semiotics, phenomenology, cultural studies, and feminism have developed. In this period, the first software programs and packages for computer-supported data analysis were developed [Geertz, 1973]. During the period from 1986 to 1990, the crisis of representation, the researchers struggled with how to locate themselves, and their subjects in reflexive texts. The focus on analyzing data was much more on interpretation than on identifying linear models. For example, the 


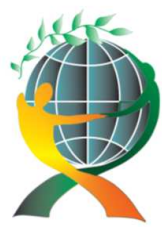

\author{
(online) $=$ ISSN $2285-3642$ \\ ISSN-L = $2285-3642$ \\ Journal of Economic Development, Environment and People \\ Volume 7, Issue 1, 2018 \\ URL: http://jedep.spiruharet.ro \\ e-mail: office jedep@spiruharet.ro
}

paradigm model suggested by Strauss and Corbin in 1990 as an orientation for coding data assumes that causes lead to phenomena [Strauss \& Corbin, 2008].

The postmodern period of qualitative research started in 1990 to 1995. It is a period of experimental and new ethnographies. During this period, narratives have replaced theories, or theories are read as narratives. The end of grand narratives is proclaimed; the accent is shifted towards theories and narratives that fit specific, delimited, local, historical situations, and problems [Denzin \& Lincoln, 2005].

The post-experimental inquiry is from 1995 to 2000. During this period qualitative research linkages to democratic policies, and becomes more prominent. The methodologically contested moment is during 2000 to 2010. It is characterized by further establishing qualitative research through various new journals. The future period is 2010 and onwards; confronts the methodological backlash associated with the evidence-based social movement. The development of qualitative research focused on the rise of evidencebased practice as the new criterion of relevance for social science, and to the new conservatism in the USA [Denzin \& Lincoln, 2005].

This history of qualitative research is limited to the USA, which has started in the 15th to 16th centuries under the banner of descriptive anthropology or ethnography [Denzin \& Lincoln, 2005]. Qualitative research has developed on North American continent in the later part of the 19th century, and which later spread also to the European continent. In Britain, qualitative research became popular through its use in educational sociology in the 1970s and 1980s [Burgess, 1985].

The first volume of the International Journal of Qualitative Studies in Education had been published in 1988; and the first volume of the journal, Qualitative Inquiry, was not published until seven years later in 1995 [Pierre, 2012].

\title{
6. Qualitative research procedures
}

Qualitative research is difficult to define clearly. It has no theory or paradigm that is distinctively its own. Nor does qualitative research have a distinct set of methods or practices that are entirely its own [Denzin \& Lincoln, 2011]. As like all kinds of research, qualitative research needs some research questions. Research questions encompass a range of topics, but most focus on participants' understanding of meanings and social life in a particular context. In qualitative research, there is a close relation between the researcher's goals and the researcher's theoretical frames. The theoretical frames consist of all the previous researches, findings or theories; existing on the topics to be studied that are mobilized by the researcher. Methodological choices are another point to prepare a qualitative research paper. These depend on which cases are selected, how the information is collected, and how the data analysis is chosen [Crescentini \& Mainardi, 2009]. The qualitative research data are descriptive, in the form of interview notes, observation records, and documents; and data are analyzed inductively. The study emphasizes on a holistic approach, and outcomes. The sources of data are real-world situations, natural, non-manipulated settings. The researcher is immersed in the details specifies of settings.

Qualitative researchers have to use key principles of research design, such as, linking the research questions to the methodological approaches, considering issues of analysis and data collection as integrated, and being clear about the purposes of the research [Mason, 1996]. 


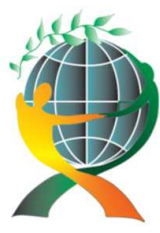

\author{
(online) $=$ ISSN $2285-3642$ \\ ISSN-L = $2285-3642$ \\ Journal of Economic Development, Environment and People \\ Volume 7, Issue 1, 2018 \\ URL: $\underline{\text { http://jedep.spiruharet.ro }}$ \\ e-mail: office jedep@spiruharet.ro
}

\title{
7. Types of qualitative research
}

Qualitative research methods typically include interviews and observations, but may also include case studies, surveys, and historical and document analyses. Qualitative research is an umbrella term used to refer to the theoretical perspectives designs as [Creswell, 2009; Hancock et al., 2009]: narrative, phenomenology, grounded theory, action research, case study, ethnography, historical research, and content analysis.

\subsection{Narrative research}

This method includes the analysis of the narrative text characteristics, and recently the ones of the meaning of inter-human relations in social, historical, and cultural contexts [Hoshmand, 2005; Felton \& Stickley, 2018]. It focuses on people's narratives either about themselves or about a set of events. Instead of looking for themes that emerge from an account, it concentrates on the sequential unfolding of someone's story so there is an emphasis on characters. It is time-consuming, and usually includes a very small number of cases [Hancock et al., 2009]. For example, a doctor takes interviews from limited number of patients, and the patients narrate the pros and cons of the diseases; and pains and sufferings of the diseases, is a narrative research.

Narrative analysis focuses on stories that told by participants. The story aspect is seen as a complete entity in itself with a beginning, middle, and an end. It is used when the study has a specific contextual focus, such as, classrooms, and students or stories about organizations, when the subject is biographical or a life history, or an oral history of personal reflections from one or more individuals. For example, a researcher wants to study the effects of physical punishment in schools in the 20th century, is a narrative research [Grbich, 2007]. In narrative research observations, diaries, letters, interviews, artifacts, and photographs collect data [Lenberg et al., 2017].

Narrative research may give unique insight into procedural and impalpable aspects of participant experience, informing project design, and illuminate context-based impacts that give greater power to local people. It allows for unique, context-based evaluations through time-oriented structures revealing how changes occur and evolve from a personal perspective. It has distinct communication features as: a set of characters developing over the course of the narrative, a plot, a sequence of events, or a temporality with more or less degrees of cause and effect, and a narrator/point of view [Constant \& Roberts, 2017].

\subsection{Phenomenological research}

The meaning of the phenomenon is conceptualized in the interior of the individual's awareness. Phenomenology is an approach to explore people's everyday life experience. It is used when the study is about the life experiences of a concept or phenomenon experienced by one or more individuals. A phenomenological researcher investigates subjective phenomena [Creswell, 2009]. For example, a thoughtful understanding of the meaningful aspects of having a conversation or a talk together or the experience of interacting online and the kind of contact or closeness we experience through email, texting, or social networks may be of value to professional practitioners as well as to anyone involved in the conversational relations of everyday living. This type of research is used to study areas in which there is little knowledge [Donalek, 2004; Guerrero-Castañeda et al., 2017]. For example, a researcher takes interview of 100 widows, and asks them to describe their experiences of the deaths of their husbands. 


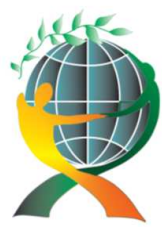

\author{
(online) $=$ ISSN $2285-3642$ \\ ISSN-L = $2285-3642$ \\ Journal of Economic Development, Environment and People \\ Volume 7, Issue 1, 2018 \\ URL: $\underline{\text { http://jedep.spiruharet.ro }}$ \\ e-mail: office jedep@spiruharet.ro
}

Creswell [2014] expressed that this type of study is the search for "The central underlying meaning of the experience that emphasize the intentionality of consciousness where experiences contain both the outward appearance and inward consciousness based on the memory, image, and meaning." For example, reading a story, having a talk with someone, sending an email or a message, listening to a piece of music, etc. are reflections of phenomenological research. Therefore, phenomenological research is a design of inquiry coming from philosophy and psychology in which the researcher describes the lived experiences of individuals about a phenomenon as described by participants [Creswell, 2014]. For example, we need to increase our knowledge about experiences of new teachers with technology and the influence of these experiences on their teaching practice and on student learning.

Edmund Husserl is the most important name in phenomenology [Husserl, 1960]. During his time, a Christian vision dominated Europe, and passed through a period of transition, from the world dominated by tradition to modern industrial era. At that time, philosophies were personal and offered answers to people's questions, to their prejudices and religious believes. Husserl's purpose was a better understanding of human basic like time, intent, color, and number [Drobot, 2012].

Phenomenology attempts to understand how participants make sense of their experiences. It is a popular study in psychology, and in some areas of nursing. It looks at subjective states so takes an insider perspective [Hancock et al., 2009; Tuffour, 2017]. A phenomenologist considers the meanings of experience, and describes the life world. Phenomenology could be difficult to understand, particularly if a person has had a limited background in philosophy [Mariano, 1990]. It is rigorous, critical, and systematic [Streubert \& Carpenter, 2002]. Although it is a challenging, exciting, and at times exhaustive process, but the final research product might be very satisfying for the researcher [Donalek, 2004].

A phenomenological researcher would ask a question such as, "What is it like for a mother to live with a teenage child who is dying of cancer?" The researcher might observe that the mother would feel very hopeless and frightened. This mother has discovered an important reason for living, whereas previously she had not felt needed anymore by her teenage child [Parse et al., 1985]. Daly [2005] has studied the lived experiences of six mothers of suicidal adolescents. She has identified six themes as: failure as a good mother, the ultimate rejection, feeling alone in the struggle, helplessness and powerlessness in the struggle, cautious parenting, and keeping an emotional distance.

\title{
7.3. Grounded theory
}

Grounded theory is developed in 1967 by two sociologists, Barney Glaser, and Anselm Strauss, in their book 'The Discovery of the Grounded Theory' from real life observations. This is an approach to theory development grounded/rooted in the data rather than empirical testing of the theory, that is, data are collected and analyzed, and then a theory is developed which is grounded in the data [Glaser \& Strauss, 1967]. These two authors defined the grounded theory as "The theory that was derived from data, systematically gathered, and analyzed through the research process" [Strauss \& Corbin, 1990]. They took the idea from symbolic internationalist that meaning is constructed using sign, languages, and symbols. The main aim of it is to generate theory from field by using observations [Walia, 2015]. For example, students could be required to reassess the power they use in leadership situations to achieve their desired results. According to Creswell, the grounded theory research is "Researcher attempts to derive a general, abstract theory of a process, action, or interaction grounded in the views of participants in a study" [Creswell, 2009]. 


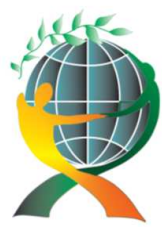

\author{
(online) $=$ ISSN $2285-3642$ \\ ISSN-L = $2285-3642$ \\ Journal of Economic Development, Environment and People \\ Volume 7, Issue 1, 2018 \\ URL: $\underline{\text { http://jedep.spiruharet.ro }}$ \\ e-mail: office jedep@spiruharet.ro
}

The basic principles of this theory are [Glaser \& Strauss, 1967]: i) The task of research is to discover new methods of understanding or investigating the social processes and interactions, and ii) The purpose of the analysis is to generate or discover a theory based on possibility fundamental patterns in life.

The grounded theory uses both an inductive and a deductive approach to the theory development. It investigates social processes and interactions among lives of people [Atkinson et al., 2001]. It deals with only inductive approach rather than deductive approach of inquiry [Glaser, 1992]. It is an appropriate way to study human behavior on a sensitive topic even in a different cultural context [Wolcott, 2009]. It is one of the data collection approach in qualitative research methods, which is totally based on data rather than try to emerge theory from data [Khan, 2014]. Here the researcher does not test hypothesis, but builds the theory from unprocessed information or from the extension of the existent theory [Yeh \& Inman, 2007]. Various data collection techniques are used to develop grounded theory, particularly interviews and observation. In this method, data are gathered through face-to-face, focus group, telephonic, etc., interviews [Tepper, 2000]. For example, if we develop a theory of identity loss and reconstruction among young people with new disabilities, we should examine our theoretical categories in other areas of life in which people have experienced a sudden major loss, such as occurs with a partner's sudden death, lay-off from work, or loss of place due to a natural disaster.

Although both authors Glaser and Strauss evolved this theory, but they parted away and gave different explanations on data analysis. Glaser avoids reviewing the literature until the first core variables have been identified. He stresses that after reviewing literature, researchers get prejudice about what to find, and the researchers get desensitized by borrowed concepts [Glaser, 1978]. Strauss indicates that to identify concepts and categories word-by-word, line-by-line analysis of data is done in open coding. He describes three coding techniques for analyzing text data as: open (identify categories), axial (flesh out and link to subcategories), and selective (form theoretical scheme). Open coding is the first step of data analysis. It is a way of identifying important words, or groups of words, in the data, and then labeling them accordingly. Axial coding is needed at the latter portions of open coding as major categories emerge from the data. In this step, researchers can explain phenomenon of the study. In selective coding researchers find out a core category, and relate it with the other major categories for generating a theory [Strauss, 1987]. Researchers are encouraged to draw on own theoretical backgrounds to inform analysis. For example, a researcher collects data from parents who have pulled their children out of public schools, and develop a theory to explain how and why this phenomenon occurs, ultimately developing a theory of school supplement.

A grounded theory report incorporates five aspects as: i) describe the research question, ii) literature review, iii) describing the methodology, iv) data analysis that explains the theory, and v) discussing the implications [Leedy \& Ormrod, 2001]. Some key features of grounded theory are as follows [Hancock et al., 2009]:

- It focuses on emergence, that is, a research should start from a position where the researcher knows nothing about what they are studying, so that all concepts truly emerge from the data.

- Sampling is based on theoretically relevant constructs.

- It supports constant comparative method, which is a useful formulation of how to do qualitative analysis and can be used separately from the other elements of grounded theory. 


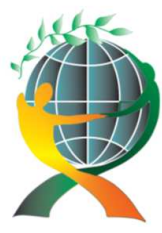

\author{
(online) $=$ ISSN $2285-3642$ \\ ISSN-L = $2285-3642$ \\ Journal of Economic Development, Environment and People \\ Volume 7, Issue 1, 2018 \\ URL: http://jedep.spiruharet.ro \\ e-mail: office jedep@spiruharet.ro
}

- Data analysis should occur at the same time as data collection to allow researchers to refine the research question, and data collection procedures in the light of new findings.

- It needs theoretical sensitivity, that is, the ability to recognize what is important in the data so that a researcher can give it meaning.

\title{
7.4. Action research
}

Action research is an emergent inquiry process that integrates theory and action to couple scientific knowledge with existing organizational knowledge; also, it address real organizational problems together with the people of the system under inquiry [Coghlan, 2011]. It has a complex history, because it is not a single academic discipline; but an approach to research that has emerged over time from a broad range of fields [Brydon-Miller et al., 2003]. For example, a school and its resources, curricula and pedagogical practices all precede and pre-figure the day-to-day enactment of the practice of education in the school, having a life of their own.

It is a type of qualitative research that seeks action to improve practice and study the effects of the action that was taken [Streubert \& Carpenter, 2002]. For example, the language conventions for communicating about human motivation are linked to certain activities, objects and settings.

It became popular in the 1940s. Kurt Zadek Lewin (1890-1947) is considered an influential personality in spreading action research. He helped the social workers to improve their practices [Lewin, 1946]. Another social psychiatrist Eric Trist (1909-1993) is also a major contributor to the action research during immediate post-war era, whose group was engaged in applied social research, initially for the civil repatriation of German prisoners of war. Eric Trist and his colleagues (Tommy Wilson, Melanie Klein, John Bowlby, Donald Winnicott, Wilfred Bion, and Jock Sutherland) are credited to focus more on large-scale, multi-organizational problems. Both Lewin and Trist applied their research to systemic change in and between organizations [Gustavsen, 2008].

Collecting and studying data is a systematic investigation performed by the teachers and other educational personnel for helping themselves to realize and develop their practices, based on the view that teachers and other educational professionals use to improve quality of teaching [Mills, 2003]. Actually, it has found support from educators; others do not consider it as a legitimate form of research and inquiry. Most of the researchers view it as an informal approach to educational research [Stringer, 1999]. It is true that this type of research plays an important role in education, using it in real situations, rather than in contrived, experimental studies, since its primary focus is on solving real problems [Brydon-Miller \& Greenwood, 2006]. For example, working with members of university human subjects review committees to develop a greater shared understanding of the constraints within which they must operate and the shared mission of the review process and action research.

\subsection{Case study}

According to A. Sturman, "A case study is a general term for the exploration of an individual, group or phenomenon" [Sturman, 1997]. Creswell [2009] defines case study as "Researcher explores in-depth a program, an event, an activity, a process, or one or more individuals". The structure of a case study should be the problem, the context, the issues, and the lessons learned [Creswell, 2014]. Hence, it is a comprehensive description of an individual case and its analysis [Mesec, 1998]. J. Sagadin states that "A 


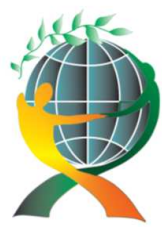

\author{
(online) $=$ ISSN $2285-3642$ \\ ISSN-L = $2285-3642$ \\ Journal of Economic Development, Environment and People \\ Volume 7, Issue 1, 2018 \\ URL: $\underline{\text { http://jedep.spiruharet.ro }}$ \\ e-mail: office jedep@spiruharet.ro
}

case study is used when we analyze and describe; each person individually for his/her activity, special needs, life situation, life history, etc.; a group of people, such as, a school department, teaching staff, etc., a problem or several problems, process, phenomenon or event in a particular institution, etc., in detail. If we remain in such analyses on the descriptive level, then a case study is considered as a form of descriptive method, but if we climb to the causal level, case study proceeds towards causal experimental method" [Sagadin, 1991]. According to H. Simons "Case study is an in-depth exploration from multiple perspectives of the complexity and uniqueness of a particular project, policy, institution, program or system in a real life" [Simons, 2009].

A case study is usually a study of a single case or a small number of cases [Sagadin, 1991]. Depending on the purpose of the study, the cases are quantitative or qualitative research; the researchers choose the design. These are in-depth examinations of people or groups of people. These are one of the first types of research to be used in the field of qualitative methodology. The case method has its roots in sociology, and has been found to be especially valuable in practice-oriented fields, such as, management, public administration, psychology, history, education, and medicine. Case studies are not used to test hypotheses, but hypotheses may be generated from case studies. A case study is time consuming and may be quite costly [Younger, 1985; Mills et al., 2010; Starman, 2013]. It is used to study one or more cases within a bounded setting or context. It is conducted by using multiple sources like: questionnaires, interviews, observations, written accounts, and audio-visual materials [Creswell, 2009]. For example, a researcher studies a classroom that is given a new curriculum for technology use, is a case study type research.

When examining one case, we refer to a singular case study, and a multiple case study is used to describe a study examining several cases. The types of singular case studies, regarding time dimension, are as follows [Thomas, 2011; Gustafsson, 2017]:

Retrospective case study: It is the simplest type of study that involves the collection of data relating to a past phenomenon of any kind. The researcher looks back on a phenomenon, situation, person, or event, and studies it in its historical integrity.

Snapshot study: The case is being examined in one particular period, such as, a current event, a day in the life of a person, a diary, etc. Here a month, a week, a day, or even a period is as short as an hour, the analysis is aided by the temporal combination of events. As the snapshot develops, the picture presents itself as a gestalt over a tight timeframe.

Diachronic study: It changes over time, and is similar to longitudinal studies.

Benefits with a single case study are that they are not as expensive and time-consuming as multiple case studies. A researcher can create a high-quality theory, because this type produces extra and better theory. It also makes the researcher to have a deeper understanding of the exploring subject. It richly can describe the existence of phenomenon [Gustafsson, 2017].

The types of multiple case studies are as follows [Thomas, 2011; George \& Bennett, 2005; Gustafsson, 2017]:

Nested studies: These involve the comparison of elements within one case, and the breakdown is within the principal unit of analysis. A nested study is distinct from a straightforward multiple studies in that it gains its integrity; its wholeness from the wider case. For example, a researcher might observe three wards within one hospital. He can take interviews from the patients' experience of cure from diseases. 


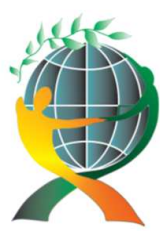

\author{
(online) $=$ ISSN $2285-3642$ \\ ISSN-L = $2285-3642$ \\ Journal of Economic Development, Environment and People \\ Volume 7, Issue 1, 2018 \\ URL: http://jedep.spiruharet.ro \\ e-mail: office jedep@spiruharet.ro
}

Parallel studies: The cases are all happening and being studied concurrently.

Sequential studies: The cases happen consecutively, and there is an assumption that what has happened at one time point or in an intervening period will affect in some way the next incident.

Theoretical idiographic case studies: These illustrative case studies do not accumulate or contribute directly to theory.

Disciplined configurative case studies: These are used to establish theories to explain the case.

Heuristic case studies: These identify new, unexpected paths; for such studies, marginal, deviant, or outlier cases may be particularly useful.

Theory-testing case studies: The studies that assess the validity and scope conditions of single or competing theories.

Plausibility probes: Preliminary studies used to determine whether further examination is warranted.

"Building Block" studies: Putting together the studies of particular types or subtypes of a phenomenon that, they contribute to a more comprehensive theory.

Multiple case studies are strong and reliable. These allow a wider discovering of theoretical evolution and research questions. When the suggestions are more intensely grounded in different empirical evidence, these create a more convincing theory [Gustafsson, 2017].

George and Bennett have identified four advantages of case studies as follows [George \& Bennett, 2005]: i) their potential to achieve high conceptual validity, ii) strong procedures for the development of new hypotheses, iii) usefulness for closely examining the hypothesized role of causal mechanisms in the context of individual cases, and iv) their capacity for addressing causal complexity.

\title{
7.6. Ethnographical research
}

Ethnographic observation is the most intensive and in-depth observational qualitative approach. The word ethnography comes from Greek ethnos, which means 'folk, people, and nation', and grapho means 'I write'. Therefore, ethnography has a setting in anthropology, which means 'portrait of a people'. It represents an approach in which the researcher engages in prolonged observations from the group's everyday life. In this type of research behaviors, values, and interactions among the members of the group are deeply studied, described, and interpreted by the researcher [Creswell, 2014]. For example, encourages children to use cameras to record their lives and challenges the concepts of; who actually makes an image, who is the photographer, who the subject, who is the observer and who the observed, is an ethnographical research.

It is the study of the beliefs, social interactions, and behaviors of small societies, involving participation and observation over a long period, and the interpretation of the data collected [Denzin \& Lincoln, 2011]. The case study studies a person, program, or event, while ethnography studies an entire group that shares a common culture [Leedy \& Ormrod, 2001; Reeves et al., 2013]. For example, an adult researcher wishing to understand the mathematical concepts of young children will find full participation in the children's world of mathematics difficult; observation will be easier.

According to Cameron [1990], ethnography is "learning from people". According to Leininger [1985], ethnography can be defined as "The systematic process of observing, detailing, describing, documenting, 


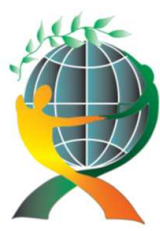

\author{
(online) $=$ ISSN $2285-3642$ \\ ISSN-L = 2285 - 3642 \\ Journal of Economic Development, Environment and People \\ Volume 7, Issue 1, 2018 \\ URL: http://jedep.spiruharet.ro \\ e-mail: office jedep@spiruharet.ro
}

and analyzing the life ways or particular patterns of a culture (or subculture) in order to grasp the life ways or patterns of the people in their familiar environment." For example, prior to the feminist movement, women entering traditional marriages expected inequality in marital relationships.

It tries to describe and analyze the culture of a community by identifying and describing the participants' practices and beliefs. It helps researchers to elucidate the situation, uncovering practices, and developing cultural awareness and sensitivity. The researcher explores with the people their rituals and customs. It is extremely time-consuming, as it involves the researcher spending long periods of time in the field [Hancock et al., 2009]. The cultural parameters are the categories of geographical, social, religion, and shared experiences. By the use of ethnographic methods, Gance-Cleveland [2004] has examined the features, critical attributes, processes, and benefits of school-based support groups for adolescents with an addicted parent. The term culture may be used in the broad sense to mean an entire Indigenous of Bangladesh. Ethnography is used when the subject involves an entire cultural group. It focuses on describing the cultures and customs of peoples. For example, a person decides to go and live in an Indigenous Community, and study the culture and their educational practices for ethnographical research purpose. For example, in human service and education programs regarding children, it is not possible for the researcher to become a student and therefore experience the setting as a child. It may be possible, however, for the research observer to participate as a volunteer, parent, or staff person in such a setting, and thereby develop the perspective of an insider in one of these adult roles.

The main characteristics of ethnographical study are as follows [LeCompte \& Schensul, 1999]:

- It is related to intimate, face-to-face interaction with participants.

- It reflects an accurate view of participants' perspectives and behaviors.

- It is conducted on natural settings, not involve with laboratory.

- It uses multiple data sources.

- It frames all human behavior and belief within a socio-political and historical context.

- It uses inductive, interactive, and recursive data collection and analytic strategies to build local cultural theories.

- It uses the concept of culture as a lens through which to interpret results.

\title{
7.7. Historical research
}

Historical research is one of the methods to describe how and where the study started, how it is developed during time, and where it stands at present [Špiláčková, 2012]. It is referred to as historiography, that is, investigation of elements from history [Berg, 2012]. F. N. Kerlinger [1972] defines historical research as "Critical investigation of events, development, and experiences of the past, careful consideration of past testimonies from the perspective of information sources validity and subsequent interpretation of the concerned testimonies." Historical research seeks not only to discover the events of the past but also to relate these past happenings to the present and to the future. According to Leininger [1985], "Without a past there is no meaning to the present, nor can we develop a sense of ourselves as individuals and as members of groups." For example, in 1609, Galileo trained his telescope for the first time on the moon, and observed previously unsuspected features, ones that he believed were not very different from those on the earth, is a historical research. 


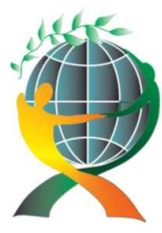

\author{
(online) $=$ ISSN $2285-3642$ \\ ISSN-L = 2285 - 3642 \\ Journal of Economic Development, Environment and People \\ Volume 7, Issue 1, 2018 \\ URL: http://jedep.spiruharet.ro \\ e-mail: office jedep@spiruharet.ro
}

The procedures of historical research are similar to other types of researches. It is the systematic collection of past data, and subsequently to identify, classify, arrange, clarify, evaluate, synthesize, elaborate, develop, and publish them by means of scientific methods. It also helps the both researchers and readers to analyze the present events and realize future ones. Many educational practices and theories can be captured properly by the use of experiences. A historical researcher can neither manipulate nor control any of the variables, as past events are unchangeable [Hroch et al., 1985].

Historical research may be more difficult to conduct comparing to some of the other types of research. According to Teresa Christy, the historical researcher must develop the "Curiosity, perseverance, tenacity, and skepticism of the detective" [Christy, 1975]. The sources of historical data are divided them into four types as follows [Danto, 2008]:

? primary sources (these are original documents found in archives),

? secondary sources (works by other authors writing about history),

? official records (official records from various institutions, case reports), and

? private materials (chronicles, autobiographies, diaries, memoirs, records of oral history).

Primary sources are firsthand information or direct evidence, and secondary sources are secondhand information [Hendl, 2005]. For example, a letter written by Florence Nightingale about nursing care during the Crimean War would be considered as a primary source of data. If a friend summarized the information about nursing care during the Crimean War based on a letter he/she received from Florence Nightingale, this source of information would be considered as a secondary source. Secondary sources have a complementary function, they originate with a time span after the described times, events or facts. For example, dictionaries, encyclopedias, biographies, obituaries, bibliographies, articles, and books are secondary sources [Danto, 2008]. There are many examples of private and official sources: oral histories, written records, diaries, eyewitnesses, pictorial sources, and physical evidences.

The data for historical research should be subjected to two types of evaluation. These evaluations are called external criticism and internal criticism. External criticism is concerned with the authenticity or genuineness of the data and should be considered first. Internal criticism examines the accuracy of the data, and is considered after the data are considered to be genuine. Whereas external criticism establishes the validity of the data, internal criticism establishes the reliability of the data. Aims of historical research are as follows [Berg, 2012]:

? to serve for revealing the unknown,

? to search for events and relations in the past whose consequences reach up to present,

? to answer questions which have not been answered yet, and

? to evaluate activities by individuals, agencies, and institutions in the past which have contributed to their today's success.

\title{
7.8. Content analysis
}

Content analysis is a method of analyzing written, verbal or visual communication messages. Leedy and Ormrod [2001] define it as "A detailed and systematic examination of the contents of a particular body of materials for the purpose of identifying patterns, themes, or biases." It was first used as a method for 


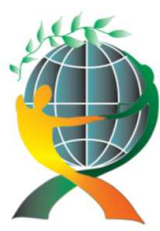

\author{
(online) $=$ ISSN $2285-3642$ \\ ISSN-L = $2285-3642$ \\ Journal of Economic Development, Environment and People \\ Volume 7, Issue 1, 2018 \\ URL: http://jedep.spiruharet.ro \\ e-mail: office jedep@spiruharet.ro
}

analyzing hymns, newspaper and magazine, articles, advertisements, and political speeches in the 19th century [Harwood \& Garry, 2003]. At present, it has a long history of use in communication, journalism, sociology, psychology, and business [Neundorf, 2002; Akşan \& Baki, 2017]. For example; through the framing of the media content, researchers can analyze the tone (negative, positive or neutral) of the news stories published by the selected newspapers.

The emphasis in conventional content analysis is on counting, where researchers would count occurrences of a word, phrase, or theme. Sociologists used it to analyze social life by interpreting words and images from documents, books, newspapers, films, arts, music, and other cultural products and media. For example, responses to open-ended questions are on the basis of content analysis [Hancock et al., 2009]. Content analysis, the examination of communication messages, is used in evaluating the data from case studies.

The collection of data in content analysis is a two-step process: i) the researcher must analyze the materials, and put them in a frequency table as each characteristics or qualities, and ii) the researcher must conduct a statistical analysis so that the results are reported in a quantitative format [Leedy \& Ormrod, 2001].

During the last few decades it has developed in continual three approaches as [Hsieh \& Shannon, 2005]; i) coding categories were derived directly from text, ii) in a direct approach to content analysis, a theory or prior research is used to guide the analysis in the initial coding, and iii) summative analysis, where counting categories precedes the interpretation.

\title{
8. Analysis of qualitative data
}

The volume of data generated complicates qualitative data analysis, and the challenge for the researcher is to conduct an in-depth analysis, and yet presents the findings in a concise and logical way [Clifford, 1997].

The data generated vary according to the type of design being used; however, they are generally subject to the same principles of analysis. Data analysis is actually a dynamic process weaving together recognition of emerging themes, identification of key ideas or units of meaning and material acquired from the literature. An intensive data analysis only starts when all data have been collected and prepared. Sometimes the process begins before all the data are collected. Each transcript is read thoroughly in its entirety. The aim at this stage is to use the data to think with, and one looks to see whether any interesting patterns can be identified [Hammersley \& Atkinson, 1983].

The researcher identifies these emerging patterns, because they appear to illuminate the research question and the literature reviewed. As the data analysis continues, these patterns begin to be developed into a number of thematic categories of description. Each transcript is then examined closely for phrases, sentences or paragraphs, i.e., participant quotes, which stand out for the researcher as central to the broader area of interest.

\section{Characteristics of qualitative research}

Qualitative research does not include statistical or empirical calculations [Brink, 1993]. The researcher is the primary instrument for data collection and analysis. It is usually involved with fieldwork. The 


\author{
(online) $=$ ISSN $2285-3642$ \\ ISSN-L = 2285 - 3642 \\ Journal of Economic Development, Environment and People \\ Volume 7, Issue 1, 2018 \\ URL: http://jedep.spiruharet.ro \\ e-mail: office jedep@spiruharet.ro
}

researchers must go to the people, setting, site, and institutions to observe behavior in its natural setting. It builds abstractions, concepts, hypothesis, or theories rather than tests existing theory. Different types of qualitative research have some common characteristics as follows [Ely et al., 1991; Hammersley \& Atkinson, 1993]:

- The researcher has the opportunity of collecting data directly from the participants through direct encounters with individuals, through one to one interviews or group interviews or by observation.

- Data are used to develop concepts and theories that help us to understand the social world.

- The sampling seeks to demonstrate representativeness of findings through random selection of subjects.

- It seeks to gain a better understanding of people's thoughts, attitudes, and behaviors.

- The researcher remains open to alternative explanations.

- It is concerned with the opinions, experiences, and feelings of individuals producing subjective data.

- It is rooted in people's everyday lives; how they experience and make sense of phenomena occurring in their lives.

- It requires clear information and detail analysis of the respondents' opinions.

- It describes social phenomena as they occur naturally.

- The data have primacy; the theoretical framework is not given previously, but can be derived from the data.

- It is conducted in 'real life' and day-to-day settings, not in controlled or laboratory settings.

- It focuses on individual and person-to-person interactions.

- A researcher needs to spend a lot of time in the research settings with the participants.

- The data are presented in a narrative form, i.e., in the words of the individuals participating.

- A researcher must avoid taking premature decision of the study.

- It is context-bound, and researchers must be context sensitive.

- It seeks to establish a holistic perspective of a given situation.

- It focuses on discovery and understanding, which requires flexibility in the research design.

- A researcher is responsible to obtain true information and to ensure the participants' ethical treatment.

- The product of it is richly descriptive.

- A researcher is an integral part of the research process. The issue is not one of minimizing the influence of the researcher, but of knowing how the researcher was involved in data collection and analysis in order to assess better the information they provide.

- It has the ability of the researcher to use their motivation and personal interest to stimulate the study.

- Data collection and data analysis proceed together. 


\author{
(online) $=$ ISSN $2285-3642$ \\ ISSN-L = $2285-3642$ \\ Journal of Economic Development, Environment and People \\ Volume 7, Issue 1, 2018 \\ URL: http://jedep.spiruharet.ro \\ e-mail: office jedep@spiruharet.ro
}

- Typically the findings are in the form of themes, categories, concepts or tentative hypotheses or theories.

\title{
10. Strengths of qualitative research
}

In qualitative research, we need to emphasize less on counting numbers of people who think or behave in certain ways, and need more emphasis on explaining why people think and behave in certain ways. It is good at simplifying and managing data without destroying complexity and context. Some major strengths of qualitative research are as follows [Yauch \& Steudel, 2003; Creswell, 2014]:

- Open-ended questioning reveals new or unanticipated phenomenon, and raises more issues through broad and open-ended inquiry.

- It includes a diverse and representative cross-section of affected persons.

- It is in-depth analysis of the impact of an emergency.

- It is rich and detailed information about affected populations.

- It allows researchers to explore the views of homogenous as well as diverse groups of people help unpack these differing perspectives within a community.

- As statistics are not used in it, and uses a more descriptive, narrative style; and gains new insight.

- It can play the important role of suggesting possible relationships, causes, effects, and dynamic processes.

- It allows people to open up and allows for new evidence, not even initially considered.

- It provides a rich picture of social phenomena and in its specific contexts reveals critical incidents.

- It provides a holistic interpretation of the detailed processes that have, and shapes people's lives.

- Its cultural assessment is the ability to probe for underlying values, beliefs, and assumptions.

- It provides insights into intra-household relations and processes.

- It offers deeper insights into causes and direction of causal processes.

- It permits researchers to access data on difficult issues, e.g., domestic violence.

- The data collection process requires limited numbers of respondents, which can be carried out with limited resources.

- Data on marginal groups that surveys often cannot locate can be collected, e.g., illegal migrants, the homeless, child-headed households.

- Because of close researcher involvement, the researcher gains an insider's view of the field, which allows the researcher to find issues that are often missed by the scientific, more positivistic enquiries.

- It encourages creativity and innovative explanatory frameworks.

- Data analyst is usually heavily involved in data collection and knows its strengths.

- Participatory methodologies empower, rather than objectify respondents.

- It adds flesh and blood to social analysis. 


\author{
(online) $=$ ISSN $2285-3642$ \\ ISSN-L = $2285-3642$ \\ Journal of Economic Development, Environment and People \\ Volume 7, Issue 1, 2018 \\ URL: http://jedep.spiruharet.ro \\ e-mail: office jedep@spiruharet.ro
}

\title{
11. Weaknesses of qualitative research
}

In qualitative research participants studies often involve smaller numbers of tools include and utilize open-ended questionnaires interview guides. Qualitative research has some weaknesses as other researches. Some major weaknesses of qualitative research are as follows [Yauch \& Steudel, 2003; Bowen, 2006]:

- Is difficult to demonstrate the scientific rigor of the data collection exercise.

- It is generally open-ended; the participants have more control over the content of the data collected.

- It does not have a preconceived, finite set of issues to examine.

- Results in data are not objectively verifiable.

- Collection of the data can be time consuming and costly. Therefore, the time required for data collection, analysis, and interpretation is lengthy.

- It needs skilled interviewers successfully carry out the primary data collection activities.

- It requires a labor-intensive analysis process, such as, categorization, recoding, etc.

- The important issue could be overlooked and go unnoticed.

- Low levels of standardization; and definitions/criteria, etc., vary from researcher to researcher.

- Contexts, situations, events, conditions, and interactions cannot be replicated to any extent, nor can generalizations be made to a wider context than the one studied with any confidence.

- The viewpoints of both researcher and participants have to be identified and elucidated because of issues of bias.

- All researchers' interpretations are limited and positioned subjects; personal experience and knowledge influence the observations and conclusions.

- It needs skilled interviewers successfully carry out the primary data collection activities.

- Completion of research is often dependents on a single individual.

- Often results cannot be generalized as it is unclear, whom they represent.

- Findings less likely to influence policy as they lack the legitimacy of science, and the precision of numbers.

- Datasets are rarely made publicly available so that findings cannot be tested, and other researchers cannot use the dataset.

- Because of the subjective nature of qualitative data and its origin in single contexts, it is difficult to apply conventional standards of reliability and validity.

- No objectively verifiable results obtained.

\section{Advantages of qualitative research}

Qualitative research reflects the detailed description of participants' feelings, opinions, and experiences; and interprets the meanings of their actions [Denzin, 1989]. The advantages of qualitative research make it possible to gather and analyze individualistic data on deeper levels. In qualitative 


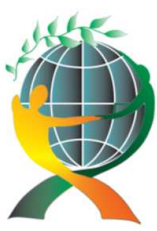

\author{
(online) $=$ ISSN $2285-3642$ \\ ISSN-L = $2285-3642$ \\ Journal of Economic Development, Environment and People \\ Volume 7, Issue 1, 2018 \\ URL: http://jedep.spiruharet.ro \\ e-mail: office jedep@spiruharet.ro
}

research, it is possible to gain new insights into consumer thoughts, demographic behavioral patterns, and emotional reasoning processes. The advantages of performing qualitative research are as follows [Conger, 1998]:

- It is flexible to follow unexpected ideas during research and explore processes effectively.

- It raises the sensitivity to contextual factors.

- A researcher has a clear vision on what to expect.

- Issues and subjects covered can be evaluated in depth and in detail.

- Smaller sample sizes are used, which save costs.

- Here subject materials can be evaluated with some greater details.

- Complexities and subtleties about the subjects of the research can be avoided in many positivistic inquiries.

- It enhances the ability to study symbolic dimensions and social meaning.

- Research frameworks are based on available data.

- Interviews are not limited to particular questions, and can be redirected by researchers in real time.

- Data are based on human experiences and observations. As a result they are more compelling and powerful.

- Data complexities can be incorporated into generated conclusions.

- It provides more contents for the creation of new ideas.

- $\quad$ The direction and framework of research can be revised quickly as soon as fresh information and findings emerge.

- It increases opportunities to develop empirically supported new ideas and theories, for in-depth and longitudinal explorations of leadership phenomena, and for more relevance and interest for practitioners.

\title{
13. Disadvantages of qualitative research
}

Qualitative research displays its own strengths however; it has also disadvantages. Qualitative research approaches sometimes leave out contextual sensitivities, and focus more on meanings and experiences [Silverman, 2010]. Purely qualitative research may neglect the social and cultural constructions of the variables studied [Richards \& Richards, 1994]. Some disadvantages are as follows:

? It is not statistically representative.

? Data rigidity is more difficult to assess, demonstrate, and maintain.

? Data are usually gathered from few individuals or cases. Therefore, findings and outcomes cannot be spread to larger populations.

[? The created data are not always accepted.

? The quantity of data makes interpretation and analysis time-consuming.

? Researcher influence can have a negative effect on the collected data. 


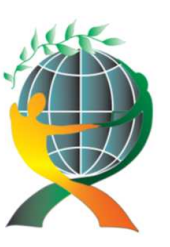

\author{
(online) $=$ ISSN $2285-3642$ \\ ISSN-L = $2285-3642$ \\ Journal of Economic Development, Environment and People \\ Volume 7, Issue 1, 2018 \\ URL: http://jedep.spiruharet.ro \\ e-mail: office jedep@spiruharet.ro
}

[? Unseen data can disappear during the research process.

[? Replicating results can be very difficult with research.

[? Difficult decisions may require repetitive research periods.

[? It is heavily dependent on the skills of the researcher, and can be easily influenced by personal idiosyncrasies and biases of researchers.

[? It is sometimes not accepted and understood especially within scientific communities.

[? Issues on confidentiality and anonymity can pose problems during presentation of findings.

[] The presence of researcher in the process of data gathering is unavoidable, and can therefore affect or influence the responses of subjects.

[? Findings can be difficult to present in visual ways.

\title{
14. Importance of quantitative research
}

Qualitative research can be used to improve both the design and interpretation of traditional surveys. It explores a phenomenon that has not been studied before. It is used to understand any social phenomenon from the perspective of the actors involved, rather than explaining it from the outside. It helps to understand complex phenomena that are difficult or impossible to capture quantitative research. The selected importance of qualitative research are as follows [Ospina, 2004]:

- It is more reliable and objective.

- It often reduces and restructures a complex problem to a limited number of variables.

- It looks at relationships between variables, and can establish cause and effect in highly controlled circumstances.

- It tests theories or hypotheses.

- It assumes sample that is representative of the population.

- Subjectivity of researcher in methodology is recognized less.

- It is less detailed than qualitative data, and may miss a desired response from the participant.

\section{Qualitative evaluation}

Evaluative criteria for qualitative studies are needed to judge vigor and truthfulness of the study findings. Credibility is the truth-value of the findings, and is based in the environmental context of the participants. Conformability is the establishment of verifiable direct evidence from the experiences the researcher has with the people. Transferability indicates that relevancies can be transferred to similar situations, circumstances, and contexts [Morris \& Burkett, 2011].

\section{Conclusion}

In this study we have highlighted the qualitative research method approaches. We have observed that this method allows the researcher to explore and better understand the complexity of a phenomenon. Obviously, the qualitative research is more complex than the quantitative research, as it deals with human mind and actions. We have discussed the types of qualitative research, such as, phenomenology, 


\author{
(online) $=$ ISSN $2285-3642$ \\ ISSN-L = $2285-3642$ \\ Journal of Economic Development, Environment and People \\ Volume 7, Issue 1, 2018 \\ URL: http://jedep.spiruharet.ro \\ e-mail: office jedep@spiruharet.ro
}

ethnography, narrative approach, grounded theory, content analysis, action research, historical research, case study in brief. We have also enlightened the characteristics, strengths, weaknesses, advantages, and importance of qualitative research. In this review paper we have tried to give an idea to the researchers to write qualitative research articles that are new in this field.

\title{
17. References
}

[1] Akşan, E., \& Baki, A. (2017). Content Analysis of Curriculum-Related Studies in Turkey between 2000 and 2014. Educational Sciences: Theory \& Practice, 17, 877-904.

[2] Atkinson, P., Coffey, A., \& Delamont, S. (2001). A Debate about Our Canon. Qualitative Research, 1(1), 5-21.

[3] Becker, H. S., Geer, B., Hughes, E., \& Strauss, A. L. (1961). Boys in White. New Brunswick, University of Chicago Press.

[4] Berg, B. L. (2012). Qualitative Research Methods for the Social Science (8th Ed.). Long Beach: Allyn and Bacon.

[5] Bowen, G. A. (2006). Document Analysis as a Qualitative Research Method. Qualitative Research Journal, 9(2), 2740.

[6] Brink, H. I. L. (1993). Validity and Reliability in Qualitative Research. Curationis, 16(2), 35-38.

[7] Brinkmann, S., Jacobsen, M. H., \& Kristiansen, S. (2014). Historical Overview of Qualitative Research in the Social Sciences. Patricia Leavy (Ed.) pp. 17-42. The Oxford Handbook of Qualitative Research. Chapter 2, Oxford: Oxford University Press.

[8] Brydon-Miller, M., \& Greenwood, D. (2006). A Reexamination of the Relationship between Action Research and Human Subjects Review Processes, Action Research, 4(1): 117-128.

[9] Brydon-Miller, M., Greenwood, D. \& Maguire, P. (2003). Why Action Research? Action Research, 1(1), 9-28.

[10] Bucea-Manea-Toniș, R., \& Radu Bucea-Manea-Joniș, R. (2017). How to Design a Web Survey Using Spring Boot with Mysql: A Romanian Network Case Study. Spiru Haret University, Faculty of Economic Sciences, 17(2), 63-71.

[11] Burgess, R. G. (1985). Issues in Educational Research: Qualitative Methods. Lewes, Falmer Press.

[12] Burns, N., \& Grove, S. K. (2009). The Practice of Nursing Research: Appraisal, Synthesis, and Generation of Evidence (6th Ed.). St. Louis, Mo: Saunders/Elsevier.

[13] Cameron, C. (1990). The Ethnographic Approach: Characteristics and Uses in Gerontological Nursing. Journal of Gerontological Nursing, 16(9), 5-7.

[14] Choy, L. T. (2014). The Strengths and Weaknesses of Research Methodology: Comparison and Complimentary between Qualitative and Quantitative Approaches, IOSR Journal of Humanities and Social Science, 19(4), 99-104.

[15] Christy, T. (1975). The Methodology of Historical Research. Nursing Research, 24, 189-192.

[16] Cibangu, K. S. (2012). Qualitative Research: The Toolkit of Theories in the Social Sciences. In Asunción LópezVarela (Ed.). Theoretical and Methodological Approaches to Social Sciences and Knowledge Management, pp. 95-126. InTech.

[17] Clifford, C. (1997). Qualitative Research Methodology in Nursing and Healthcare. Open Learning Foundation/Churchill Livingstone, Edinburgh.

[18] Coghlan, D., (2011). Action Research: Exploring Perspectives on a Philosophy of Practical Knowing. Academy of Management Annals, 5(1), 53-87. 


\author{
(online) $=$ ISSN $2285-3642$ \\ ISSN-L = $2285-3642$ \\ Journal of Economic Development, Environment and People \\ Volume 7, Issue 1, 2018 \\ URL: http://jedep.spiruharet.ro \\ e-mail: office jedep@spiruharet.ro
}

[19] Conger, J. (1998). Qualitative Research as the Cornerstone Methodology for Understanding Leadership. Leadership Quarterly, 9(1), 107-121.

[20] Constant, N., \& Roberts, E. (2017). Narratives as a Mode of Research Evaluation in Citizen Science: Understanding Broader Science Communication Impacts. Journal of Science Communication, 16(4), A03:1-18.

[21] Crescentini, A., \& Mainardi, G. (2009). Qualitative Research Articles: Guidelines, Suggestions and Needs. Journal of Workplace Learning, 21(5), 431-439.

[22] Creswell, J. W. (2009). Research Design: Qualitative, Quantitative and Mixed Method Approaches (3rd Ed.). Los Angeles: SAGE Publications.

[23] Creswell, J. W. (2014). Qualitative Inquiry \& Research Design: Choosing among Five Approaches (4th Ed.). Thousand Oaks, CA: SAGE.

[24] Daly, P. (2005). Mothers Living with Suicidal Adolescents: A Phenomenological Study of Their Experiences. Journal of Psychosocial Nursing \& Mental Health Services, 43(3), 22-28.

[25] Danto, E. A. (2008). Historical Research. Pocket Guides to Social Work Research Methods. New York: Oxford University Press.

[26] Denzin, N. K. (1989). Interpretive Interactionism. Newbury Park, CA: SAGE.

[27] Denzin, N. K., \& Lincoln, Y. S. (2005). Introduction: The Discipline and Practice of Qualitative Research. In N. K. Denzin \& Y. S. Lincoln (Eds.). The SAGE Handbook of Qualitative Research (3rd Ed.), pp. 1-32. Thousand Oaks, CA: SAGE.

[28] Denzin, N. K., \& Lincoln, Y. S. (Eds.) (2011). The SAGE Handbook of Qualitative Research (5th Ed.). Thousand Oaks, CA: SAGE Publications.

[29] Domholdt, E. (1993). Physical Therapy Research: Principles and Applications. W B Saunders, Philadelphia.

[30] Donalek, J. G. (2004). Demystifying Nursing Research: Phenomenology as a Qualitative Research Method. Urologic Nursing, 24, 516-517.

[31] Drobot, L. (2012). Qualitative Research in Social Sciences and Education-Basic Paradigms and Research Methods. Research in Pedagogy, 2(2), 11-20.

[32] Dudwick, N., Kuehnast, K., Jones, V. N., \& Woolcock, M. (2006). Analyzing Social Capital in Context: A Guide to Using Qualitative Methods and Data, World Bank Institute, Washington.

[33] Edwards, J. (2016). Conducting Action Research on the Effects of Cognitive Coaching and Adaptive Schools. Thinking Collaborative, Maximizing Capacity in Individuals and Organizations.

[34] Ely, M., Anzul, M., Friedman, T., Garner, D., \& Steinmetz, A. (1991). Doing Qualitative Research: Circles within Circles. London: Falmer Press.

[35] Felton, A., \& Stickley, T. (2018). Rethinking Risk: A Narrative Approach. Journal of Mental Health Training, Education and Practice, 13(1), 54-62.

[36] Flick, U. (2014). An Introduction to Qualitative Research (5th Ed.). SAGE, London.

[37] Gance-Cleveland, B. (2004). Qualitative Evaluation of a School-Based Support Group for Adolescents with an Addicted Parent. Nursing Research, 53, 379-386.

[38] Garfinkel, H. (1967). Studies in Ethnomethodology. Englewood Cliffs, NJ: Prentice Hall. 


\author{
(online) $=$ ISSN $2285-3642$ \\ ISSN-L = $2285-3642$ \\ Journal of Economic Development, Environment and People \\ Volume 7, Issue 1, 2018 \\ URL: http://jedep.spiruharet.ro \\ e-mail: office jedep@spiruharet.ro
}

[39] Geertz, C. (1973). The Interpretation of Cultures: Selected Essays. New York: Basic Books.

[40] Gentles, S. J., Charles, C., Ploeg, J., \& McKibbon, K. (2015). Sampling in Qualitative Research: Insights from an Overview of the Methods Literature. The Qualitative Report, 20(11), 1772-1789.

[41] George, A. L., \& Bennett, A. (2005). Case Studies and Theory Development in the Social Science. Cambridge: MIT Press.

[42] Glaser, B. G. (1978). Theoretical Sensitivity. Sociology Press: Mill Valley CA.

[43] Glaser, B. G. (1992). Emergence vs. Forcing: Basics of Grounded Theory Analysis. Mill Valley, CA: Sociology Press.

[44] Glaser, B. G., \& Strauss, A. (1967). The Discovery of Grounded Theory: Strategies for Qualitative Research. New York, NY, Aldine De Groyter.

[45] Gopaldas, A. (2016). A Front-to-back Guide to Writing a Qualitative Research Article, Qualitative Market Research: An International Journal, 19(1), 115-121.

[46] Grbich, C. (2007). Qualitative Data Analysis: An Introduction. London: SAGE Publications.

[47] Greenhill, A., Holmes, K., Woodcock, J., Lintott, C., Simmons, B. D., Graham, G., Cox, J., Oh, E. Y., \& Masters, K. (2016). 'Playing with Science'. Aslib Journal of Information Management, 68(3), 306-325.

[48] Guerrero-Castañeda, R. F., Menezes, T. M. O., Ojeda-Vargas, M. G. (2017). Scenario Approximation in a Phenomenological Study in Mexico: Experience Report. Revista Brasileira de Enfermagem [Internet], 70(4), 885890.

[49] Gustavsen, B. (2008). Action Research, Practical Challenges and the Formation of Theory. Action Research, 6(4), 421-437.

[50] Gustafsson, J. (2017). Single Case Studies vs. Multiple Case Studies: A Comparative Study. Academy of Business, Engineering and Science, Halmstad University, Halmstad, Sweden.

[51] Hammersley, M., \& Atkinson, P. (1983). Ethnography: Principles in Practice. Routledge, London.

[52] Hancock, B., Ockleford, E., \& Windridge, K. (2009). An Introduction to Qualitative Research, National Institute for Health Research (NIHR). The NIHR RDS EM/YH.

[53] Harwood, T. G., \& Garry, T. (2003). An Overview of Content Analysis. The Marketing Review, 3, 479-498.

[54] Hatch, J. A. (2002). Doing Qualitative Research in Educational Settings. Albany: State University of New York Press.

[55] Hendl, J. (2005). Kvalitativní Výzkum. Základní Metody a Aplikace. (Qualitative Research. Basic Methods and Application) Praha: Portál.

[56] Hoshmand, L. T. (2005). Narratology, Cultural Psychology, and Counseling Research. Journal of Counseling Psychology, 52, 178-186.

[57] Hroch, M. et al. (1985). Úvod do Studia Dějepisu (An Introduction to History Studies). Praha: Státní Pedagogické Nakladatelství, pp. 208-214.

[58] Hsieh, H., \& Shannon, S. (2005). Three Approaches to Qualitative Content Analysis. Qualitative Health Research, $15,1277-1288$.

[59] Husserl, E. (1960). Cartesian Meditation: An Introduction of Phenomenology. Translated by Dorion Cairns. The Hague: Nijhoff. 


\author{
(online) $=$ ISSN $2285-3642$ \\ ISSN-L = $2285-3642$ \\ Journal of Economic Development, Environment and People \\ Volume 7, Issue 1, 2018 \\ URL: http://jedep.spiruharet.ro \\ e-mail: office jedep@spiruharet.ro
}

[60] Jones-Goods, K. M. \& Grant, M. C. (2016). A Phenomenological Study of Cultural Responsiveness in Special Education. Journal of Research Initiatives, 2(1), Article 17, 1-10.

[61] Kerlinger, F. N. (1972). Základy Výzkumu Chování. Pedagogický a Psychologický Výzkum. (Foundations of Behavioural Research. Pedagogical and Psychological Research.) Praha: Academia.

[62] Khan, S. N. (2014). Qualitative Research Method: Grounded Theory. International Journal of Business and Management, 9(11), 224-233.

[63] LeCompte, M. D., \& Schensul, J. J. (1999). Designing and Conducting Ethnographic Research, Lanham, MD: AltaMira Press.

[64] Leedy, P. \& Ormrod, J. (2001). Practical Research: Planning and Design (7th Ed.). Upper Saddle River, NJ: Merrill Prentice Hall. Thousand Oaks: SAGE Publications.

[65] Leininger, M. M. (Ed.) (1985). Qualitative Research Methods in Nursing. Orlando, FL: Grune \& Stratton.

[66] Lenberg,_P., Feldt, R., Tengberg, L. G. W., Tidefors, I., \& Graziotin, D. (2017). Behavioral Software EngineeringGuidelines for Qualitative Studies. arXiv:1712.08341v1 [cs.SE] 22 Dec 2017

[67] Levitt, H. M., Motulsky, S. L., Wertz, F. J., Morrow, S. L., \& Ponterotto, J. G. (2017). Recommendations for Designing and Reviewing Qualitative Research in Psychology: Promoting Methodological Integrity. Qualitative Psychology, 4(1), 2-22.

[68] Lewin, K. (1946). Action Research and Minority Problems. Journal of Social Issues, 2(4), 34-46.

[69] Maestrini, V., Luzzini, D., Shani, A. B., \& Canterino, F. (2016). The Action Research Cycle Reloaded: Conducting Action Research Across Buyer-Supplier Relationships. Journal of Purchasing \& Supply Management, 22, $289-298$.

[70] Mainowski, B. (1925). Argonauts of the Western Pacific: An Account of Native Enterprise and Adventure in the Archipelagos of Melanesian New Guinea. New York, Datton.

[71] Mariano, C. (1990). Qualitative Research: Instructional Strategies and Curricular Considerations. Nursing \& Health Care, 11, 354-359.

[72] Mason, J. (1996). Qualitative Researching. London, SAGE Publications.

[73] Maxwell, J. A. (2016). Expanding the History and Range of Mixed Methods Research. Journal of Mixed Methods Research, 10(1), 12-27.

[74] Mead, M. (1935). Sex and Temperament in Three Primitive Societies. New York, Marrow.

[75] Mesec, B. (1998). Uvod v Kvalitativno Raziskovanje v Socialnem Delu. Ljubljana: Visoka Šola za Socialno Delo.

[76] Mills, A. J., Durepos, G., \& Wiebe, E. (2010). Encyclopedia of Case Study Research. London: SAGE.

[77] Mills, G. E. (2003). Action Research: A Guide for the Teacher Researcher (2nd Ed.). Upper Saddle River, NJ: Prentice Hall.

[78] Mohajan, H. K. (2017). Two Criteria for Good Measurements in Research: Validity and Reliability. Annals of Spiru Haret University Economic Series, 17(3), 58-82.

[79] Morris, E., \& Burkett, K. (2011). Mixed Methodologies: A New Research Paradigm or Enhanced Quantitative Paradigm. Online Journal of Cultural Competence in Nursing and Healthcare, 1(1), 27-36.

[80] Neundorf, K. (2002). The Content Analysis Guidebook. SAGE Publications Inc., Thousand Oaks: CA. 


\author{
(online) $=$ ISSN $2285-3642$ \\ ISSN-L = $2285-3642$ \\ Journal of Economic Development, Environment and People \\ Volume 7, Issue 1, 2018 \\ URL: http://jedep.spiruharet.ro \\ e-mail: office jedep@spiruharet.ro
}

[81] Ospina, S. (2004). Qualitative Research. In G. Goethals, G. Sorenson, \& J. MacGregor (Eds.). Encyclopedia of Leadership, pp. 1279-1284. London: SAGE.

[82] Park, R., \& Burgess, E. (1925). The City. Chicago, University of Chicago Press.

[83] Parse, R. R., Coyne, A. B., \& Smith, M. J. (1985). Nursing Research: Qualitative Methods. Bowie, MD: Brady.

[84] Paul, K. B. (2017). Introducing Interpretive Approach of Phenomenological Research Methodology in Environmental Philosophy: A Mode of Engaged Philosophy in the Anthropocene. International Journal of Qualitative Methods, 16, 1-10.

[85] Pierre, E. A. S. (2012). A Brief and Personal History of Qualitative Research. Journal of Curriculum Theorizing, 30(2), 1-19.

[86] Pistol, L., \& Bucea-Manea-Tonis, R. (2017). Model of Simulation for Optimizing Marketing Mix through Conjoint Analysis Case Study: Launching a Product on a New Market. Economics World, 5(4), 311-315.

[87] Polkinghorne, D. E. (2005). Language and Meaning: Data Collection in Qualitative Research. Journal of Counseling Psychology, 52, 137-145.

[88] Punch, K. F. (2013). Introduction to Social Research: Quantitative and Qualitative Approaches. SAGE Publications.

[89] Rahman, M. S. (2017). The Advantages and Disadvantages of Using Qualitative and Quantitative Approaches and Methods in Language "Testing and Assessment" Research: A Literature Review. Journal of Education and Learning, 6(1), 102-112.

[90] Reeves, S., Peller, J., Goldman, J., \& Kitto, S. (2013). Ethnography in Qualitative Educational Research: AMEE Guide No. 80, Medical Teacher, 35(8), e1365-e1379.

[91] Remenyi, D. S. J., Swartz, E., Money, A., \& Williams, B. (1998). Doing Research in Business and Management: An Introduction to Process and Method. SAGE Publications, London.

[92] Richards, T. J., \& Richards, L. (1994). Using Computers in Qualitative Research. In N. Denzin, \& Y. Lincoln (Eds.), Handbook of Qualitative Research. pp. 445-462. London: Sage Publications.

[93] Sagadin, J. (1991). Razprave iz Pedagoške Metodologije. Ljubljana: Znanstveni Inštitut Filozofske Fakultete.

[94] Shayb, H. A. (2017). Restructuring Companies under Crisis a Real Case Study. Annals of Spiru Haret University Economic Series, 17(3), 141-147.

[95] Silverman, D. (2010). Qualitative Research. London: SAGE.

[96] Simons, H. (2009). Case Study Research in Practice. SAGE, London.

[97] Spencer, L., Ritchie, J., Lewis, J., \& Dillon, L. (2003). Quality in Qualitative Evaluation: A Framework for Assessing Research Evidence. A Quality Framework. National Centre for Social Research, Cabinet Office, London.

[98] Špiláčková, M. (2012). Historical Research in Social Work-Theory and Practice. ERIS Web Journal, 3(2), 22-33.

[99] Spradley, J. P. (1980). Participant Observation. New York: Fort Worth, Harcourt Brace Johanovich College Publishers.

[100] Starman, A. B. (2013). The Case Study as a Type of Qualitative Research. Journal of Contemporary Educational Studies, 1, 28-43.

[101] Strauss, A. (1987). Qualitative Research for Social Scientists. Cambridge: Cambridge University Press. 


\author{
(online) $=$ ISSN $2285-3642$ \\ ISSN-L = $2285-3642$ \\ Journal of Economic Development, Environment and People \\ Volume 7, Issue 1, 2018 \\ URL: http://jedep.spiruharet.ro \\ e-mail: office jedep@spiruharet.ro
}

[102] Strauss, A., \& Corbin, J. (2008). Basics of Qualitative Research: Techniques and Procedures for Developing Grounded Theory (3rd Ed.). Thousand Oaks, London, New Delhi: SAGE Publications.

[103] Streubert, H. J., \& Carpenter, D. R. (2002). Qualitative Research in Nursing: Advancing the Humanistic Imperative (3rd Ed.). Philadelphia: Lippincott Williams \& Wilkins.

[104] Stringer, E. T. (1999). Action Research. Thousand Oaks, CA: SAGE.

[105]Sturman, A. (1997). Case Study Methods. In J. P. Keeves (Ed.). Educational Research, Methodology and Measurement: An International Handbook (2nd Ed.). pp. 61-66. Oxford: Pergamon.

[106] Tepper, B. J. (2000). Consequences of Abusive Supervision. Academy of Management Journal, 43(2), 178-190.

[107] Thomas, G. (2011). A Typology for the Case Study in Social Science Following a Review of Definition, Discourse and Structure. Qualitative Inquiry, 17(6), 511-521.

[108] Tong, A., Flemming, K., McInnes, Oliver, E. S., \& Craig, J. (2012). Enhancing Transparency in Reporting the Synthesis of Qualitative Research: ENTREQ. BMC Medical Research Methodology, 12: 181.

[109] Tuffour, I. (2017). A Critical Overview of Interpretative Phenomenological Analysis: A Contemporary Qualitative Research Approach. 2(4), 52(1) -52(5).

[110] Viswambharan, A. P. \& Priya, K. R. (2016). Documentary Analysis as a Qualitative Methodology to Explore Disaster Mental Health: Insights from Analyzing a Documentary on Communal Riots. Qualitative Research, 16(1) 43-59.

[111].Walia, R. (2015). A Saga of Qualitative Research. Social Crimonol, 5(2), 124.

[112] Williams. A. M., \& Irurita, V. F. (2005). Enhancing the Therapeutic Potential of Hospital Environments by Increasing the Personal Control and Emotional Comfort of Hospitalized Patients. Applied Nursing Research, 18, 22-28.

[113] Williams, C. (2007). Research Methods. Journal of Business \& Economic Research, 5(3), 65-71.

[114] Wolcott, H. (2009). Writing up Qualitative Research (3rd Ed.). Thousand Oaks, CA: SAGE.

[115] Yauch, C. A., \& Steudel, H. J. (2003). Complementary Use of Qualitative and Quantitative Cultural Assessment Methods, Organizational Research Methods, 6(4), 465-481.

[116] Yeh, J. C., \& Inman, A. G. (2007). Qualitative Data Analysis and Interpretation in Counseling Psychology: Strategies for Best Practices. The Counseling Psychologist, 35(3), 369-403.

[117] Younger, J. (1985). Practical Approaches to Clinical Research: The Case Study. Pediatric Nursing, 11, 137.

[118]Zohrabi, M. (2013). Mixed Method Research: Instruments, Validity, Reliability and Reporting Findings. Theory and Practice in Language Studies, 3(2), 254-262. 